\title{
PENGARUH PENAMBAHAN KARET REKLIM DARI LIMBAH OUTSOLE TERHADAP SIFAT FISIS DAN SIFAT THERMAL PRODUK OUTSOLE SEPATU (STUDI KASUS DI CV. CARITA NIAGA)
}

\author{
Muh. Wahyu Syabani ${ }^{1}$, Fikri Irfani Fauziyyah ${ }^{1}$, Tintin Mutiara ${ }^{2}$ \\ 1) Jurusan Teknologi Pengolahan Karet dan Plastik, Politeknik ATK Yogyakarta \\ 2) Jurusan Teknik Kimia, Fakultas Teknologi Industri, Universitas Islam Indonesia \\ E-mail : muh.wahyu.s@mail.ugm.ac.id
}

\begin{abstract}
Abstrak
Limbah padat industri karet sukar mengalami degradasi di alam sehingga memerlukan pengelolaan dengan baik. Penelitian ini bertujuan untuk mempelajari pengaruh penambahan karet reklim dari limbah outsole terhadap sifat fisis dan sifat thermal dari produk outsole. Pencampuran karet dan bahan aditif lainnya dilakukan menggunakan mesin kneader dan open mill sedangkan proses vulkanisasi dilakukan dengan mesin hydraulic press. Variasi yang digunakan adalah jumlah karet reklim yang ditambahkan yaitu 12,5; 37,5 dan 62,5 phr. Hasil penelitian ini menunjukan bahwa produk outsole dengan penambahan karet reklim memberikan hasil organoleptis berupa permukaan rata, tidak retak, tidak pecah, tidak kotor dan kesamaan ukuran untuk semua variasi. Pengujian fisis menunjukan ketahanan kikis, kuat tarik dan perpanjangan putus akan mengalami penurunan, sedangkan nilai kekerasan cenderung naik dengan penambahan karet reklim. Ketahanan retak lentur menunjukan hasil untuk penambahan 12,5 dan 37,5 phr dalam kondisi baik dan tidak retak, sedangkan pada 62,5 phr sudah mengalami keretakan. Hasil pengujian kestabilan thermal menunjukan bahwa sampel memiliki kestabilan thermal relatif sama. Hasil penelitian ini menunjukan jika penambahan karet reklim dari limbah outsole sampai 37,5 phr memiliki potensi tinggi sebagai filler pada kompon karet untuk outsole.
\end{abstract}

Kata Kunci : limbah industri karet, karet reklim, karakteristik fisis, kestabilan thermal

Abstract

Rubber solid waste are very difficlult to naturally degradated so its needed a good waste handling. The aims of this research was to study the effect of reclaimed rubber made from rubber solid waste that used as an outsole filler on physical and thermal properties of the outsole products. The mixing of rubber and the additives using kneder and open mill and the vulcanization process was carried using hydraulic press. The research design using three variation of the raclaimed rubber addition; 12,5; 37,5 and 62,5 phr. The organoleptics testing results shows that all the variation has good outsole surface, not broken, clean and similar size. The physical testing shows that for higher reclaimed rubber addition gives better hardness but lower abrasion resistance, tensile stength and elongation. The thermal stability for each of the sample are relatively similar since the reclaimed rubber are from the outsole waste itself. Therefore, the reclaimed rubber has highly potential as a filler of the outsole product for addition lower that 37,5 phr.

Keywords : rubber waste; reclaimed rubber; physical characteristic, thermal stability 


\section{PENDAHULUAN}

Indonesia adalah salah satu negara penghasil karet terbesar di dunia. Sementara itu, karet merupakan material yang penting ( $\mathrm{Li}$ et al., 2010) dan pemakaiannya terus mengalami perkembangan. Perkembangan ini pada suatu titik akan menjadi sumber masalah karena industri pengolahan karet menghasilkan limbah yang berpotensi mencemari apabila dibuang ke lingkungan (Yuniari, 2006). Limbah karet membutuhkan waktu yang sangat lama untuk terdegradasi secara alami karena struktur crosslink pada karet dan keberadaan stabilisator serta aditif lainnya (Adhikari et al., 2000).

Upaya penanganan limbah karet tersebut sudah banyak dilakukan. Landfill merupakan salah satu cara penanganan limbah karet yang paling awal dilakukan. Akan tetapi, metode ini memiliki kelemahan yaitu semakin terbatasnya ketersediaan lahan dan potensi pencemaran lingkungan karena kandungan aditif pada produk karet dapat mengalami leaching dan membunuh bakteri menguntungkan yang ada di dalam tanah (Adhikari et al., 2000). Metode lain yang dapat dilakukan adalah penggunaan limbah karet sebagai bahan bakar untuk pembangkit listrik (Bomberger et al., 1980) maupun pirolisis (Shigeo et al., 1980). Metode ini juga berpotensi mencemari udara karena menghasilkan sejumlah besar karbon dan memiliki nilai recovery limbah karet yang rendah (Adhikari et al., 2000).

Berbagai penelitian sudah dilakukan untuk menemukan metode baru dalam daur ulang limbah karet (Formela et al., 2015). Limbah karet dapat dirubah bentuknya dan digunakan sebagai filler untuk menggantikan sebagian karet baru pada kompon karet (Setyowati et al., 2006; Formela et al., 2015). Penggunaan kembali limbah karet sebagai bahan baku produk akan membantu pemecahan masalah limbah padat karet (Navarro et al., 2005) sekaligus dapat mengurangi biaya produksi dan memperbaiki karakteristik proses seperti keseragaman dan kestabilan dimensi produk akhir (Setyowati et al., 2006). Karet reklim dapat bercampur lebih cepat dan menghasilkan panas lebih sedikit dibandingkan dengan karet baru, sehingga energi pencampuran yang dibutuhkan juga akan lebih sedikit (Adhikari et al, 2000). Akan tetapi, karakteristik mekanis dari vulkanisasi karet reklim ini lebih rendah dibandingkan dengan karet baru (Phadke et al., 1983). Oleh karena itu, karet reklim dapat dimanfaatkan untuk pembuatan barang-barang karet yang tidak menuntut kekuatan tinggi, sebagai contoh karpet dan outsole (Setyowati et al., 2006). Sifat fisis dan karakteristik pemrosesan dari karet reklim dapat diperbaiki melalui pencampuran dengan karet baru. 
Kendala yang dialami usaha daur ulang adalah tingkat kebutuhan biaya dari solid handling, seperti transportasi dan penyimpanan. Masih sedikit penelitian yang berusaha memanfaatkan karet reklim sebagai bahan baku di industri penghasil limbah karet itu sendiri. Pemanfaatan limbah karet untuk konsumsi produsen penghasil limbah secara langsung akan mampu mengurangi jumlah output limbah yang dikeluarkan ke lingkungan sehingga dapat menciptakan industri zero waste.

Penelitian ini mengangkat pemanfaatan karet reklim dari limbah outsole yang digunakan sebagai filler pada pembuatan produk outsole baru dan bertujuan untuk mempelajari pengaruh jumlah karet reklim terhadap karakteristik mekanis dan thermal dari outsole yang dihasilkan. Solusi ini diharapkan dapat mengurangi jumlah limbah karet yang dihasilkan tanpa mengurangi kualitas dari produk.

\section{METODE PENELITIAN}

\subsection{Bahan Penelitian}

Bahan baku yang digunakan adalah karet brown crepe, karet compo crepe, karet reklim (dari limbah outsole). Bahan aditif yang digunakan adalah zinc oksida, asam stearat, G90, TMQ, kaolin, carbon black, silika, oli bekas, TMTM, CBS, dan sulfur yang diperoleh dari CV. Carita Niaga.

\subsection{Peralatan Penelitian}

Alat yang digunakan dalam penelitian ini meliputi alat proses dan alat uji yang terdiri dari kneader, open mill, hydraulic press, tensile strength tester merek Troning tipe QCII-M-18, hardness tester merek Toyoseiki, TG/DTA merek Perkins Elmer Diamond Series.

\subsection{Variabel Penelitian}

Dalam penelitian ini faktor yang dipelajari adalah jumlah karet reklim yang ditambahkan pada kompon karet. Jumlah karet reklim yang ditambahkan divariasikan sebesar 12,5; 37,5; dan 62,5 phr dari berat karet.

\subsection{Prosedur Penelitian}

Limbah karet outsole di cacah dan diperkecil ukurannya. Karet reklim ditambah bahan baku karet, zinc oksida, asam stearat, TMQ dan G90 secara berurutan dimastikasi dan diaduk hingga homogen dalam kneader selama 15 menit dan suhu $70^{\circ} \mathrm{C}$. Selanjutnya pada campuran 
ditambahkan carbon black, silika, kaolin dan oli di aduk lanjut dalam kneader selama 15 menit dan suhu $70^{\circ} \mathrm{C}$. Kompon karet yang dihasilkan ditambahkan TMTM, CBS dan sulfur kemudian digiling dalam open mill selama 15 menit dan suhu $70^{\circ} \mathrm{C}$. Lembaran kompon yang sudah didinginkan selanjutnya divulkanisasi dengan menggunakan hydraulic press pada suhu $160^{\circ} \mathrm{C}$, tekanan $10 \mathrm{~kg} / \mathrm{cm}^{2}$ dengan waktu 15 menit. Vulkanisat berupa outsole karet yang dihasilkan siap untuk diujikan.

\subsection{Pengujian}

Vulkanisat yang dihasilkan diuji sifat organoleptis, sifat fisis dan kestabilan thermal. Uji secara organoleptis dilakukan sesuai dengan standar dari perusahaan PT. Carita Niaga, yaitu pengujian permukaan, keretakan, pecah, kotor dan ukuran. Uji fisis meliputi nilai kekerasan (SNI 0778:2009), ketahanan retak lentur (SNI 0778:2009), ketahanan kikis (ISO 4649), kuat tarik dan perpanjangan putus (ISO 37). Pengujian kestabilan thermal menggunakan TG/DTA Perkins Diamond Series dengan tipe pan terbuka dan berat sampel $5 \mathrm{mg}$. Suhu operasi dari $30^{\circ} \mathrm{C}$ sampai $1000^{\circ} \mathrm{C}$ dengan kecepatan kenaikan suhu $10^{\circ} \mathrm{C} /$ menit.

\section{HASIL DAN PEMBAHASAN}

\subsection{Limbah karet outsole}

Limbah outsole yang dihasilkan CV. Carita Niaga terdiri atas hasil trimming dan produk akhir yang mengalami cacat berupa kehilangan bentuk, benjol dan cekung sebagaimana terlihat pada Gambar 1 .

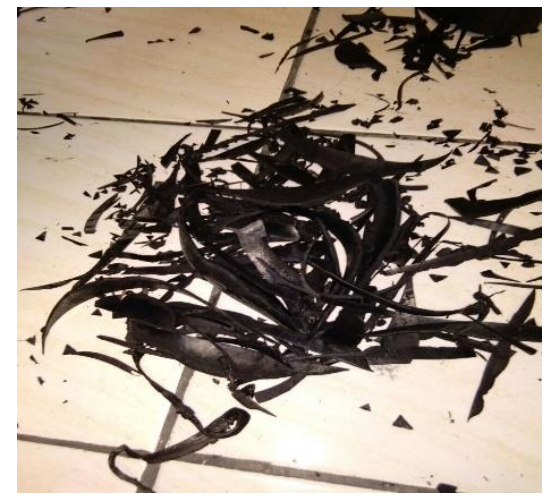

(a)

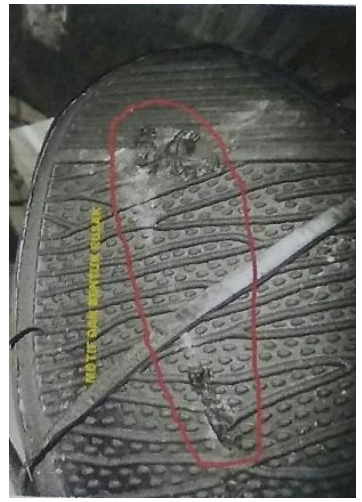

(b) 


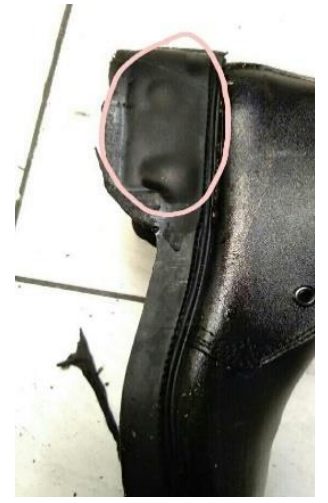

(c)

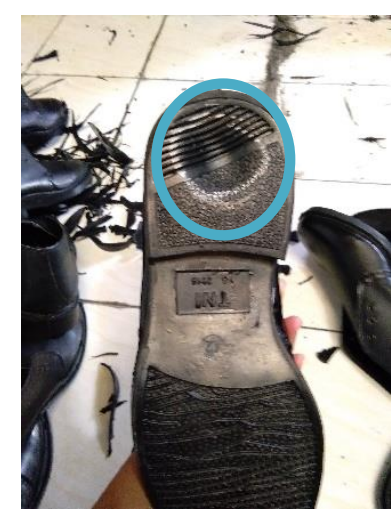

(d)

Gambar 1. Limbah outsole

(a) Sisa hasil trimming, (b) Outsole kehilangan bentuk, (c) Outsole benjol, (d) Outsole cekung Sumber: CV. Carita Niaga, 2017

Limbah outsole tersebut kemudian dikecilkan ukurannya menggunakan crusher dan partikel kecilnya akan digunakan sebagai filler pada produksi outsole baru. Karet reklim dari limbah outsole sebagaimana terlihat pada gambar 1 berwarna gelap (hitam) sehingga umumnya dipakai untuk pembuatan barang-barang karet yang berwarna gelap juga (Setyowati et al., 2006). Oleh karena itu, pemanfaatannya untuk filler pembuatan outsole baru dengan warna yang sama (hitam) sudah sangat sesuai.

\subsection{Uji Organoleptis}

Uji secara organoleptis dilakukan menurut standar dari perusahaan PT. Carita Niaga, yaitu uji permukaan, keretakan, pecah, kotor dan ukuran. Produk outsole yang dihasilkan terlihat pada Gambar 2, sedangkan hasil pengujian disajikan pada Tabel 1 di bawah ini. 


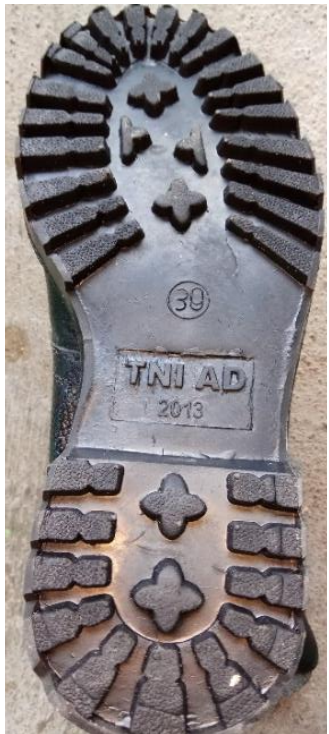

(a)

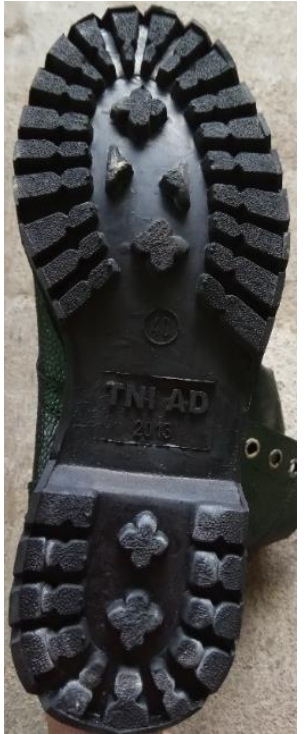

(b)

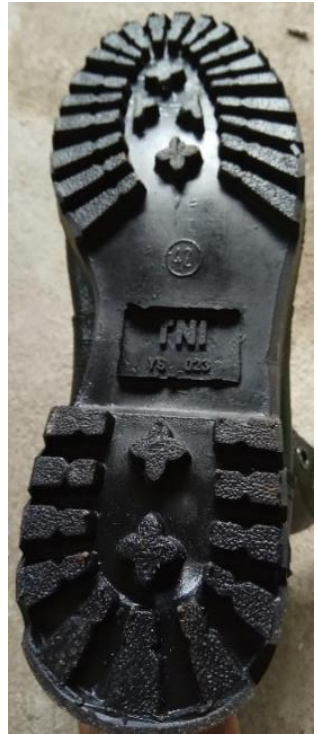

(c)

Gambar 2. Outsole sepatu PDL TNI dengan variasi penambahan karet reklim (a) $12,5 \mathrm{phr}$, (b) $37,5 \mathrm{phr}$, dan (c) $62,5 \mathrm{phr}$

Sumber : CV. Carita Niaga, 2017

Tabel 1. Hasil Pengujian Organoleptis

\begin{tabular}{llccc}
\hline \multirow{2}{*}{ No } & \multirow{2}{*}{ Kriteria Pengujian } & \multicolumn{3}{c}{ Karet reklim, phr } \\
\cline { 3 - 5 } & & 12,5 & 37,5 & 62,5 \\
\hline 1 & Permukaan rata & $\sqrt{ }$ & $\sqrt{ }$ & $\sqrt{ }$ \\
2 & Tidak retak & $\sqrt{ }$ & $\sqrt{ }$ & $\sqrt{ }$ \\
3 & Tidak pecah & $\sqrt{ }$ & $\sqrt{ }$ & $\sqrt{ }$ \\
4 & Tidak kotor & $\sqrt{ }$ & $\sqrt{ }$ & $\sqrt{ }$ \\
5 & Nomor sol kanan dan kiri sama & $\sqrt{ }$ & $\sqrt{ }$ & $\sqrt{ }$ \\
\hline
\end{tabular}

Kriteria pengujian tersebut merupakan standar dari perusahaan dan setiap sampel yang lolos quality control dinyatakan layak untuk dipasarkan ke konsumen. Berdasarkan Tabel 1 tersebut, terlihat bahwa dari rentang 12,5 sampai $62,5 \mathrm{phr}$ dinyatakan lolos quality control dengan kondisi permukaan rata, tidak ada keretakan, tidak ada pecah, tidak kotor dan kesamaan ukuran kiri dan kanan. Hasil uji organoleptis sangat tergantung pada ukuran partikel RR yang digunakan. Partikel yang berukuran makin kecil akan menghasilkan homogenitas kompon yang semakin baik. Homogenitas kompon ini memberikan pengaruh yang signifikan pada produk akhir outsole sepatu (BPTK, 2005), dimana kompon yang tidak homogen akan menimbulkan potensi keretakan pada produk saat dicetak. Menurut Setyowati (2006), kelebihan dari karet reklim adalah keseragamannya (uniformity). 


\subsection{Pengujian Fisis}

Hasil pengujian fisis yang dilakukan meliputi kekerasan, ketahanan kikis, ketahanan retak lentur, kuat tarik dan perpanjangan putus. Terlihat pada hasil pengujian fisis yang disajikan pada Tabel 2 di bawah ini, keseluruhan parameter sudah sesuai dengan SNI kecuali untuk kekerasan dan ketahanan retak lentur untuk 62,5 phr.

Tabel 2. Hasil Pengujian Fisis

\begin{tabular}{|c|c|c|c|c|c|}
\hline \multirow{2}{*}{ No } & \multirow{2}{*}{ Pengujian } & \multicolumn{3}{|c|}{$\mathrm{RR}, \%$} & \multirow{2}{*}{ SNI-0306-1989-A } \\
\hline & & 12,5 & 37,5 & 62,5 & \\
\hline 1 & Kekerasan, shore A & 69,00 & 69,33 & 71,33 & Minimal 80 \\
\hline 2 & $\begin{array}{l}\text { Ketahanan kikis, } \\
\mathrm{mm}^{3} / \mathrm{kgm}\end{array}$ & 0,01074 & 0,01183 & 0,01229 & Maksimal 1 \\
\hline 3 & $\begin{array}{l}\text { Ketahanan retak lentur, } \\
200.000 \text { kali }\end{array}$ & $\begin{array}{l}\text { Baik tidak } \\
\quad \text { retak }\end{array}$ & $\begin{array}{l}\text { Baik tidak } \\
\quad \text { retak }\end{array}$ & Retak & $\begin{array}{l}\text { Baik, tidak retak } \\
\text { atau putus }\end{array}$ \\
\hline 4 & Kuat tarik, $\mathrm{kgf} / \mathrm{cm}^{2}$ & 94,14 & 90,40 & 80,28 & - \\
\hline 5 & Perpanjangan putus, $\%$ & 280,00 & 260,00 & 253,33 & Minimal 250 \\
\hline
\end{tabular}

\subsubsection{Pengaruh penambahan karet reklim terhadap kekerasan}

Kekerasan merupakan sifat yang sangat mempengaruhi penampilan dan ketahanan barang jadi karet. Nilai kekerasan dari kompon karet erat kaitannya dengan jumlah filler dan softener (Yuniari, 2006). Pengaruh jumlah karet reklim tehadap nilai kekerasan dari outsole disajikan pada Gambar 3 di bawah ini.

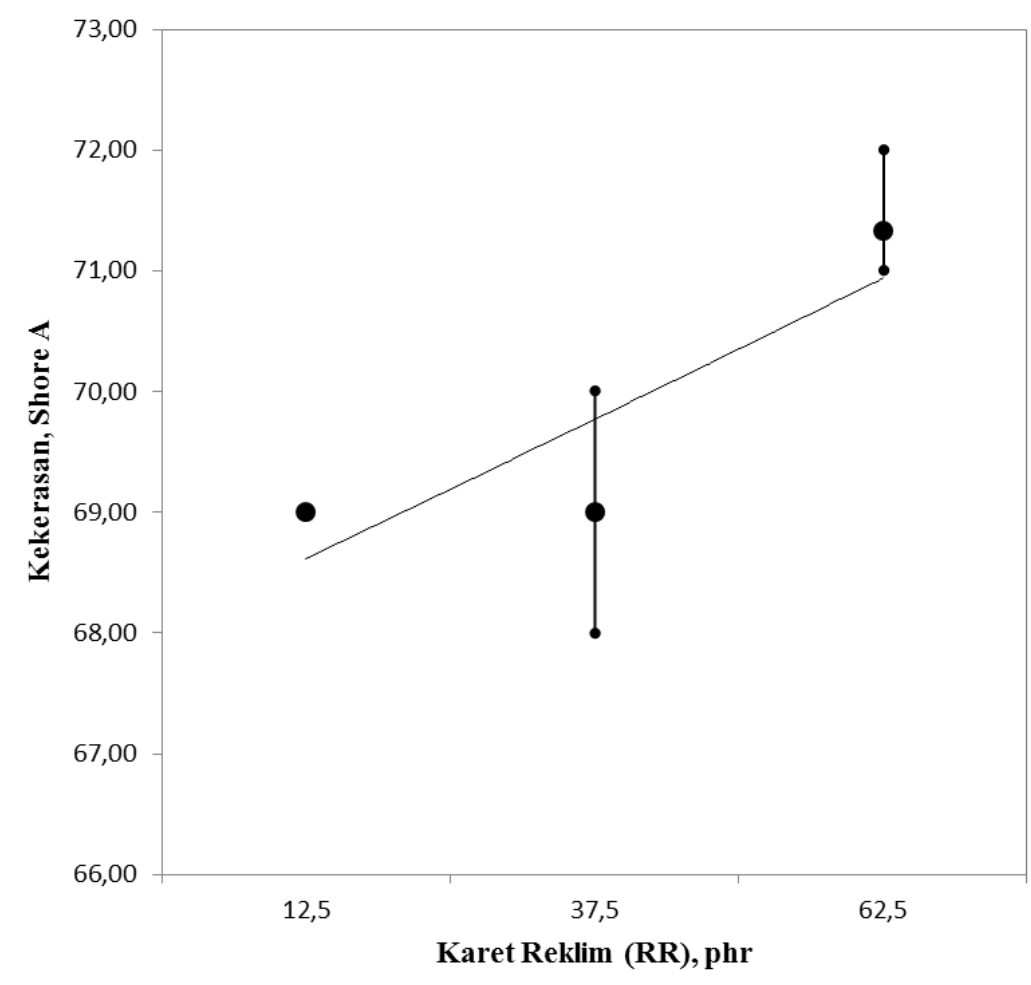

Gambar 3. Grafik hasil pengujian tingkat kekerasan 
Dari Gambar 3 terlihat bahwa semakin banyak karet reklim yang ditambahkan maka nilai kekerasan dari vulkanisat juga akan semakin naik. Kecenderungan ini selaras dengan hasil penelitian sejenis yang dilakukan oleh Setyowati (2006). Nilai kekerasan dan sifat mekanik akan naik dengan naiknya nilai crosslink density dari vulkanisat (Yuniari et al., 2013; Formela et al., 2015). Kenaikan crosslink density dipengaruhi oleh banyaknya ikatan silang yang terbentuk (Syabani et al., 2017). Penambahan karet reklim sebagai filler akan memberikan jumlah ikatan silang yang semakin banyak karena sudah membawa ikatan silang monosulfida yang dihasilkan dari proses vulkanisasi sebelumnya.

\subsubsection{Pengaruh karet reklim terhadap ketahanan kikis}

Ketahanan kikis adalah kemampuan karet bertahan terhadap gesekan dengan benda lain dan dinyatakan sebagai volume karet yang terkikis oleh alat uji (Luftinor, 2015). Semakin sedikit jumlah yang terkikis menunjukan vulkanisat karet yang semakin baik. Pengaruh jumlah karet reklim tehadap nilai ketahanan kikis dari outsole disajikan pada Gambar 4 di bawah ini.

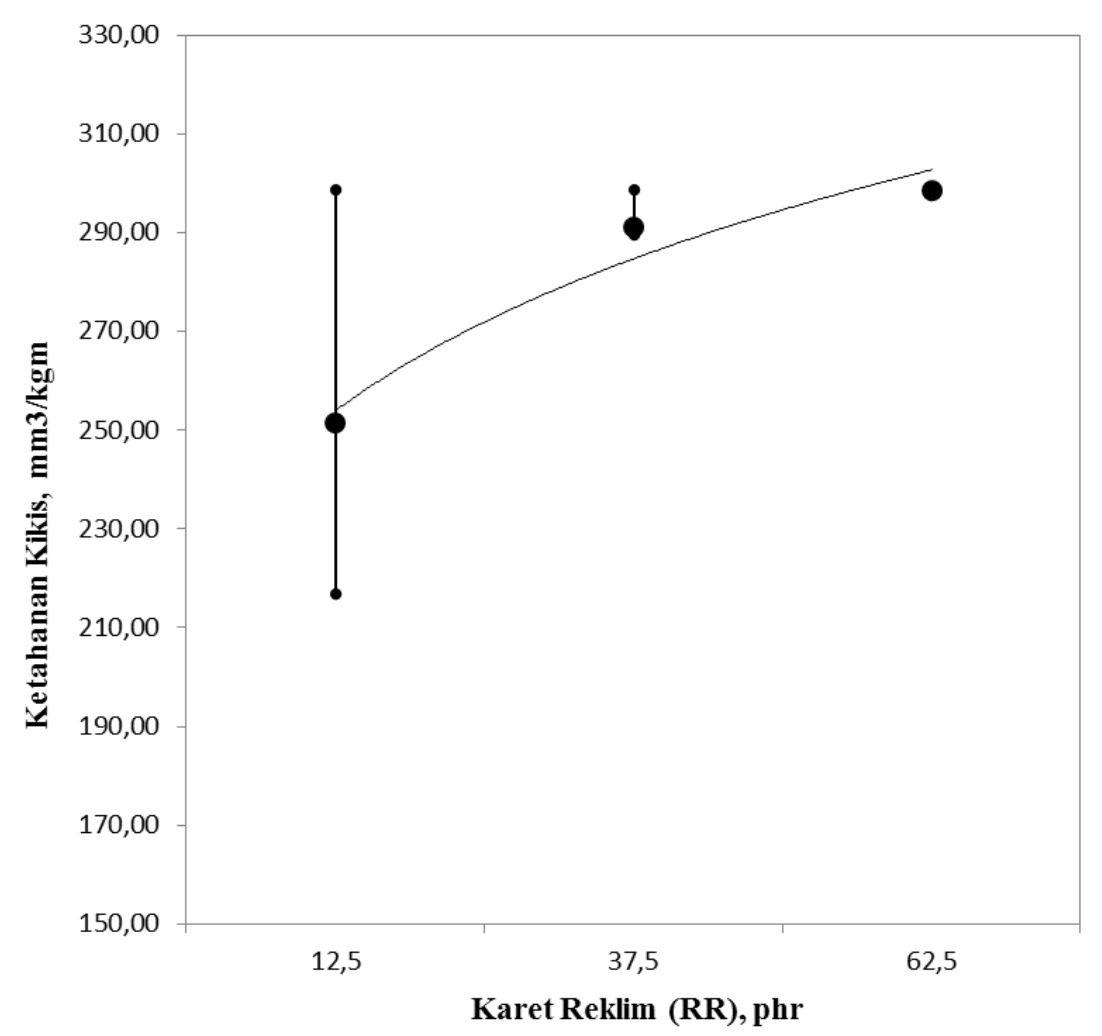

Gambar 4. Grafik hasil pengujian ketahanan kikis

Ketahanan kikis merupakan parameter yang sangat penting pada outsole karena pada saat digunakan outsole akan mengalami gesekan dengan permukaan jalan yang dilewati. Pada Gambar 4 di atas, terlihat bahwa semakin banyak jumlah karet reklim akan menghasilkan 
jumlah karet yang terkikis semakin banyak sehingga menunjukan ketahanan kikis yang semakin turun. Rendahnya karakteristik mekanik dari vulkanisat yang mengandung karet reklim disebabkan oleh dua faktor utama, yaitu lemahnya interaksi antara elastomer-filler dan perubahan nilai crosslink density (Formela et al., 2015). Lemahnya interaksi ini dikarenakan limbah karet sudah mengalami vulkanisasi sehingga lebih sukar membentuk ikatan silang dibandingkan dengan karet baru sehingga ikatan yang dibentuk karet reklim pu lebih lemah dibandingkan karet baru.

\subsubsection{Pengaruh karet reklim terhadap ketahanan retak lentur}

Uji ketahanan retak lentur dilakukan untuk mengetahui tingkat kerusakan kompon karet jika dibengkuk berulang kali secara terus-menerus. Nilai ketahanan ini erat kaitannya dengan jumlah filler dan softener (Yuniari, 2006). Semakin banyak filler yang ditambahkan akan membuat sifat elastisitas vulkanisat mengalami penurunan. Dari tabel 2 di atas, terlihat bahwa penambahan karet reklim sebagai filler akan memberikan nilai ketahanan retak lentur yang semakin rendah. Hal ini dikarenakan ikatan rangkap dari karet reklim sudah mengikat sulfur sehingga sulit membentuk ikatan silang dengan molekul karet alam baru (Prayitno et al., 1990). Sedikitnya jumlah ikatan silang baru yang terbentuk ini menyebabkan outsole lebih mudah mengalami keretakan.

\subsubsection{Pengaruh penambahan karet reklim terhadap kuat tarik}

Kuat tarik adalah kekuatan yang digunakan untuk menarik vulkanisat (kompon) karet sampai putus dan dihitung persatuan luas. Pengaruh jumlah karet reklim tehadap nilai kuat tarik dari outsole disajikan pada Gambar 5 di bawah ini. 


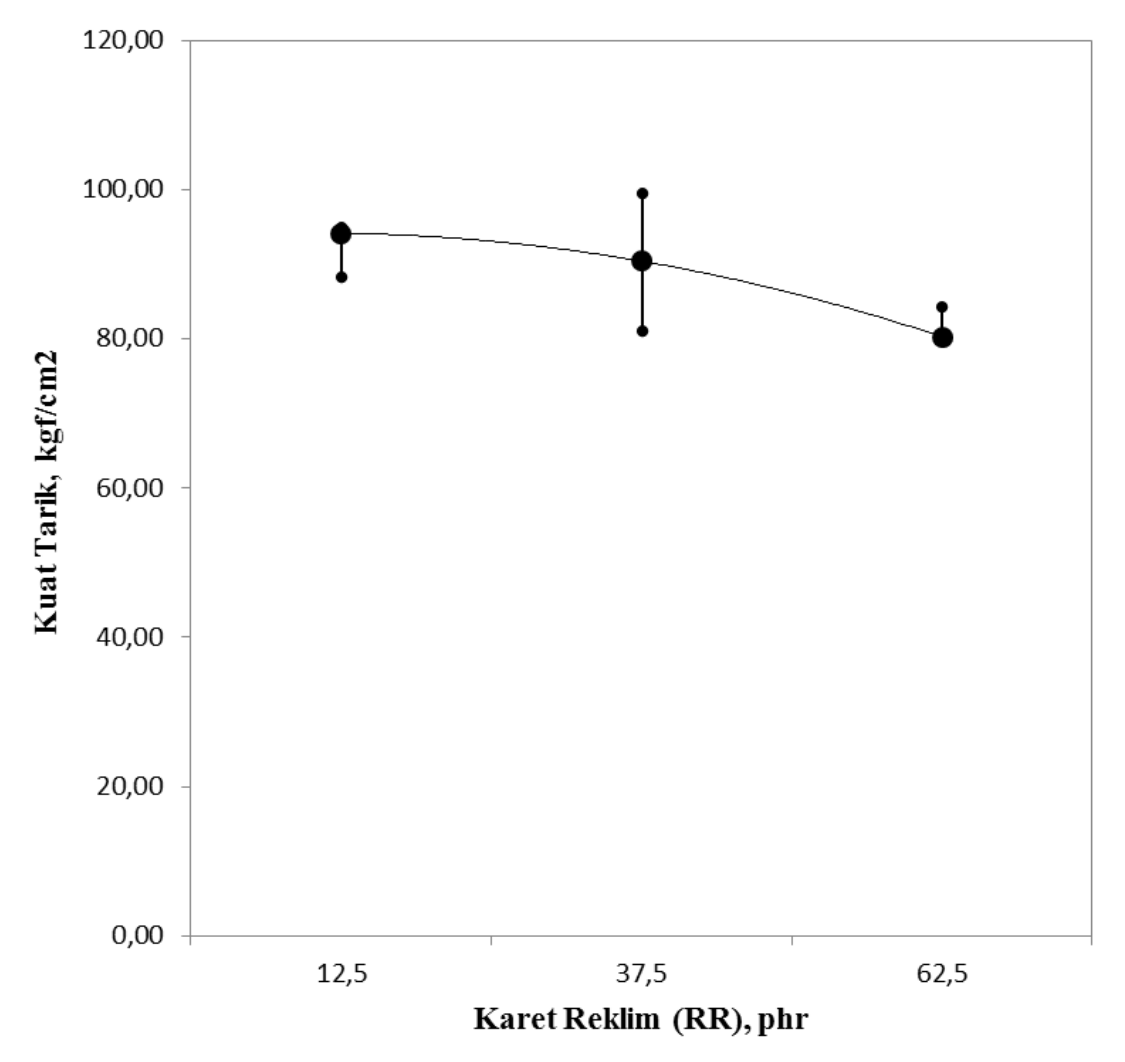

Gambar 5. Grafik hasil pengujian kuat tarik

Karet reklim yang tidak di treatment, ketika ditambahkan ke karet baru akan menaikan viskositas dan menurunkan nilai kuat tarik (Ajam et al., 2016). Sifat tersebut diakibatkan rendahnya daya rekat antara permukaan RR-matriks. Sehingga karet reklim biasanya digunakan untuk filler untuk produk karet dimana penurunan sifat fisis dapat diterima. Oleh karena itu, pemanfaatan karet reklim lebih cocok untuk aplikasi non teknis, seperti lantai, karpet dan sepatu.

\subsubsection{Pengaruh penambahan karet reklim terhadap perpanjangan putus}

Perpanjangan putus merupakan kemampuan vulkanisat meregang apabila ditarik sampai putus dan dinyatakan dalam persen dari panjang potongan uji sebelum diregangkan. Nilai pengujian ini merupakan salah satu indikasi sifat elastisitas dari produk karet (Luftinor, 2015). 


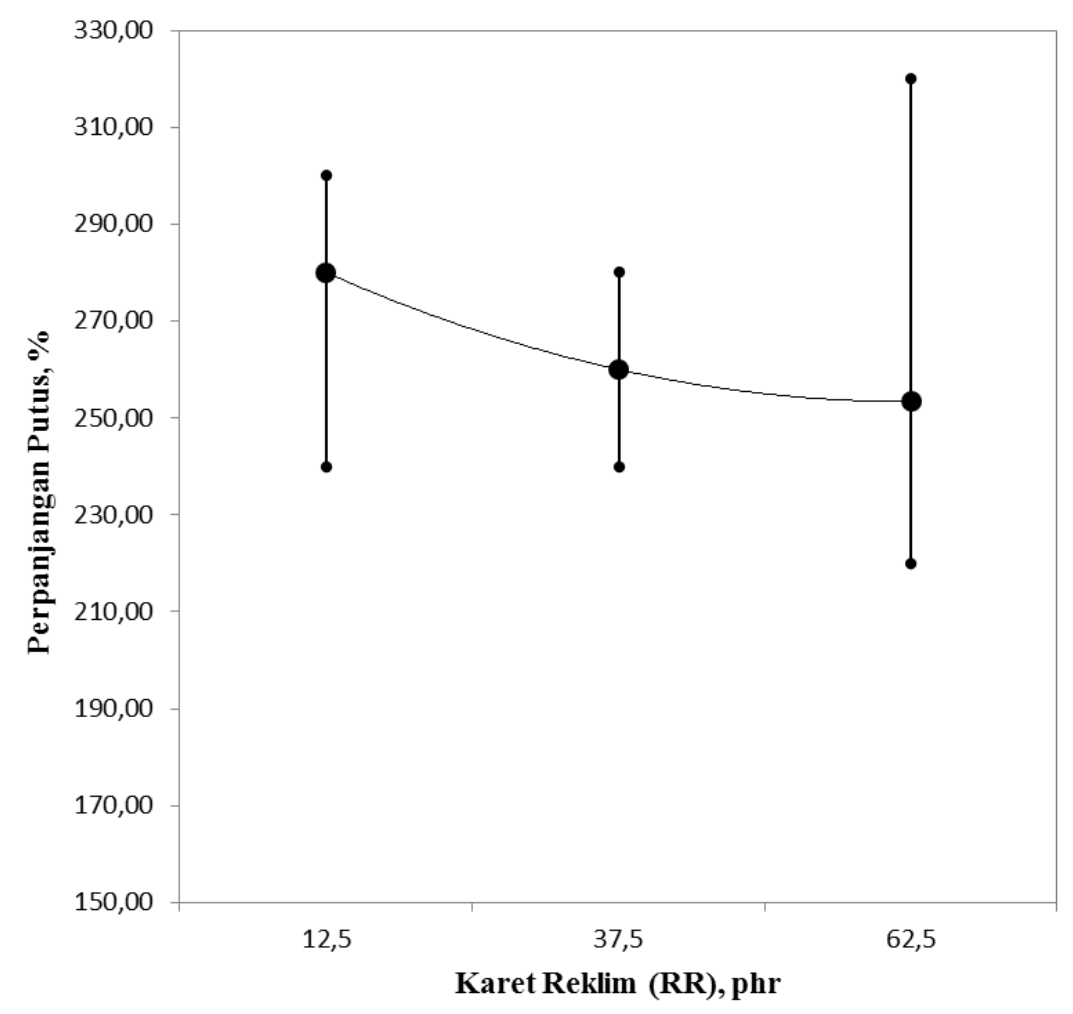

Gambar 6. Grafik hasil pengujian perpanjangan putus

Pada Gambar 6 menunjukan bahwa nilai perpanjangan putus dari vulkanisat akan semakin turun sejalan dengan penambahan karet reklim pada rentang 12,5 sampai 62,5 phr. Karet reklim sudah mengalami vulkanisasi yang menyebabkan terbentuknya ikatan silang diantara rantai polimer. Ikatan silang yang terbentuk tersebut mengakibatkan pergerakan/slip antar rantai polimer terbatas sehingga elastisitas karet reklim tidak sebaik karet virgin (Setyowati et al., 2006). Dengan demikian dapat dikatakan bahwa karet reklim menyebabkan vulkanisat berkurang elastisitasnya.

\subsection{Analisis Thermal}

Setiap material jika mengalami perlakukan panas akan mengalami perubahan struktur yang mengakibatkan adanya perubahan energi thermal material tersebut (Yuniari et al., 2013, Yu et al., 2016). Hasil pengujian terlihat pada Gambar 7 di bawah ini. 


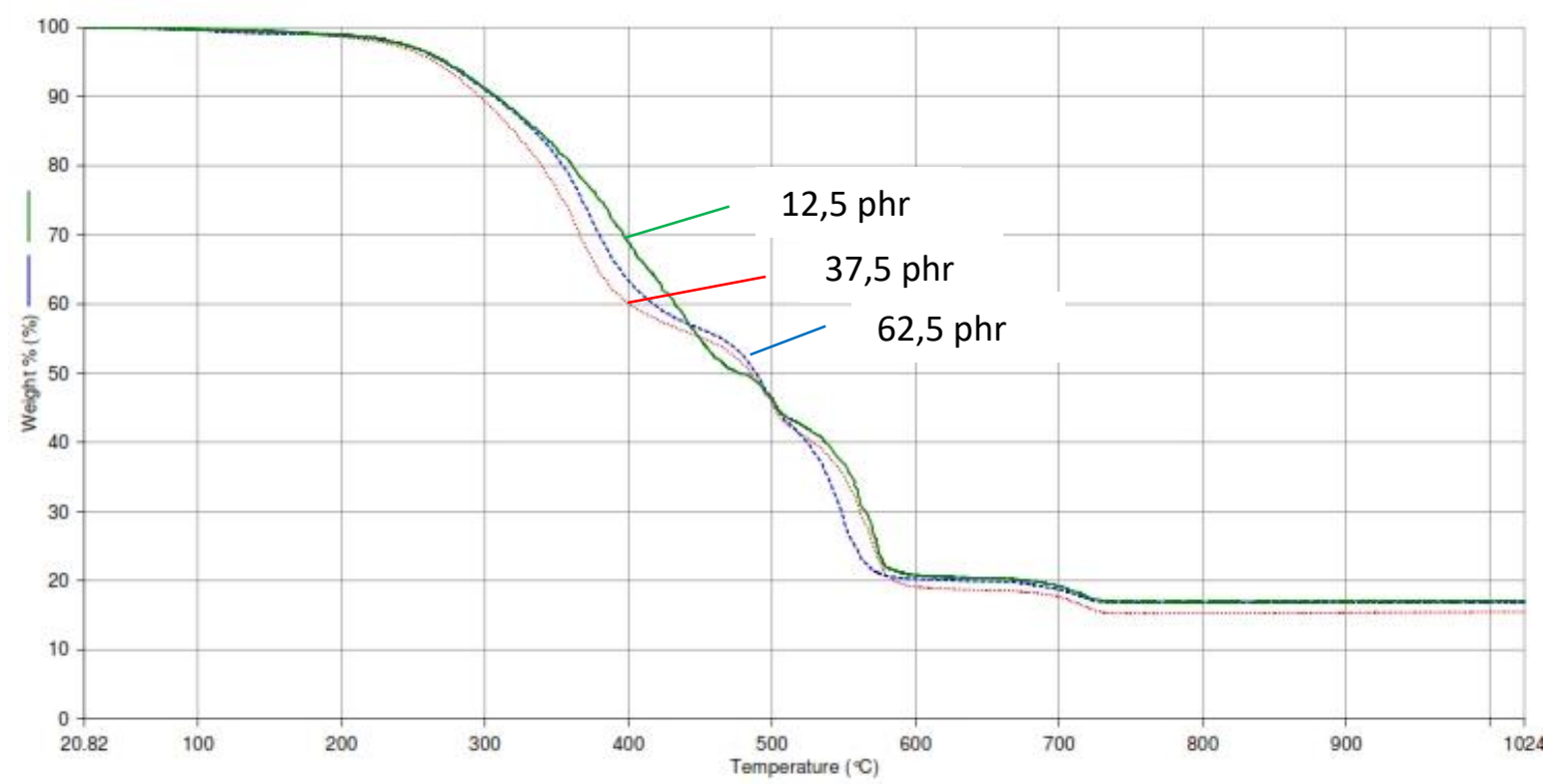

Gambar 7. Kurva thermogravimetric (TG) dari outsole

Kurva thermogravimetric untuk suhu di bawah $250^{\circ} \mathrm{C}$ memiliki kecenderungan penurunan berat yang sama dikarenakan hilangnya senyawa volatil. Dekomposisi karet secara umum terjadi dalam 2 langkah (Li et al., 2010). Pada Gambar 7, terlihat bahwa langkah pertama terjadi pada rentang suhu $250-580^{\circ} \mathrm{C}$ dengan kehilangan berat sebesar $78 \%$. Hal ini merupakan dekomposisi thermal dari rantai utama karet tervulkanisasi. Terlihat pada kurva bahwa secara umum semakin banyak penambahan karet reklim akan membuat dekomposisi berjalan sedikit lebih cepat. Hal ini dikarenakan ikatan yang dibentuk karet reklim tidak sekuat karet baru. Langkah dekomposisi kedua terjadi pada rentang suhu $580-720^{\circ} \mathrm{C}$ dengan penurunan berat yang sudah sangat lambat yaitu kurang dari $4 \%$. Ketiga kurva dari sampel memiliki tren yang hampir sama, hal ini dikarenakan ketiga sampel memiliki bahan baku yang sama. Karet reklim yang digunakan pada penelitian juga berasal dari limbah outsole itu sendiri sehingga memiliki komposisi bahan penyusun yang relatif sama dengan kompon karetnya. Menurut Li (2010), tahapan kedua tersebut adalah proses karbonisasi. Pada suhu di atas $720^{\circ} \mathrm{C}$ berat sudah relatif tidak berubah lain dan menyisakan abu.

Tabel 3. Ash content dari outsole

\begin{tabular}{cc}
\hline Penambahan RR (phr) & Ash content (\%) \\
\hline 12,5 & 17,0408 \\
37,5 & 15,4709 \\
62,5 & 16,8928 \\
\hline
\end{tabular}


Kestabilan thermal secara keseluruhan diindikasi salah satunya dari nilai ash content, dimana nilai yang lebih besar menunjukkan kestabilan polimer yang lebih baik (Syabani et al., 2017). Berdasarkan Tabel 3 di atas, diketahui jika nilai ash content dari ketiga variasi memiliki nilai yang relatif sama. Dengan demikian dapat diambil kesimpulan bahwa penambahan karet reklim sampai dengan 62,5 phr memberikan kestabilan thermal keseluruhan yang relatif sama juga. Kestabilan thermal ini sangat penting pada PDL karena jenis sepatu ini digunakan oleh personil militer untuk berbagai medan operasi.

\section{KESIMPULAN}

Karet reklim dari limbah outsole dapat digunakan sebagai filler pada pembuatan kompon outsole yang baru sehingga mengurangi jumlah limbah karet yang dihasilkan. Uji organoleptis menunjukkan bahwa penambahan filler 12,5 sampai dengan 62,5 phr memberikan hasil yang sesuai dengan standar pabrik. Uji fisis menunjukan bahwa penambahan karet reklim dapat menaikan nilai kekerasan dan menurunkan nilai ketahanan kikis, kuat tarik dan perpanjangan putus sehingga sesuai untuk pembuatan outsole yang tidak membutuhkan spesifikasi teknik yang tinggi. Sementara itu, penambahan karet reklim sebanyak 62,5 phr mengalami keretakan pada uji ketahanan retak lentur. Analisis thermal menunjukan bahwa vulkanisat terdekomposisi dalam dua langkah yaitu antara suhu 250$580^{\circ} \mathrm{C}$ dan $580-720^{\circ} \mathrm{C}$ serta memiliki kestabilan thermal yang relatif sama. Dengan demikian, jumlah penambahan karet reklim yang disarankan sebagai filler outsole adalah maksimum 32,5 phr yang memiliki nilai kekerasan 69,33 shore A, ketahanan kikis $0,01183 \mathrm{~mm}^{3} / \mathrm{kgm}$, ketahanan retak lentur baik, kuat tarik $90,40 \mathrm{kgf} / \mathrm{cm}^{2}$ dan perpanjangan putus $260 \%$.

\section{UCAPAN TERIMAKASIH}

Penulis mengucapkan terimakasih kepada CV. Carita Niaga atas bantuannya dalam pengambilan data. Terimakasih juga diucapkan kepada Politeknik ATK Yogyakarta atas dukungan sarana dan prasarananya. 


\section{DAFTAR PUSTAKA}

Adhikari, B., De, D., Maiti, S., (2000), Reclamation and Recycling of Waste Rubber, Prog. Polym. Sci., 25, pp. 909-948

Ajam, A.M., Al-Nesrawy, S.H., Al-Maamori, M., (2016). Effect of Reclaim Rubber Loading on The Mechanical Properties of SBR Compoisite. Int. J. Chem. Sci., 14(4), pp. 24392449

Badan Standarisasi Nasional, SNI-0306-1989-A, Sepatu Dinas Lapangan ABRI Sol dan Hak Karet Hitam Sistem Vulkanisasi, BSN, Jakarta.

Bomberger, D.C. and Jones, J.L., (1980), An Evaluation of Modular Incinerators for Energy Recovery From Solid Wastes, ACS Symposium Series Vol. 130, Thermal Conversion of Solid Wastes and Biomass Chapter 6, pp. 67-83.

BPTK, (2005), Kursus Singkat Teknologi Barang Jadi Karet Padat, Balai Penelitian Teknologi Karet, Bogor.

Formela, K., Wasowicz, D., Formela, M., Hejna, A., Haponiuk, J. (2015). Curing Characteristics, Mechanical and Thermal Properties of Reclaimed Ground Tire Rubber Cured with Various Vulcanizing Systems, Iran Polym. J. 24 (4), pp. 289-297

Li, C., Zhong, J., Yang, L., Li, S., Kong, L., Hou, T., (2010), Studies on the Properties and The Thermal Decomposition Kinetics of Natural Rubber Prepared with Calcium Chloride, e-Polymers, 072, pp. 1-9

Luftinor, (2015), Penggunaan Karet Alam Untuk Pembuatan Rubber Cots Mesin Ring Spinning, Balai Riset dan Standardisasi Industri Palembang, Palembang.

Navarro, F.J., Partal, P., Martinez-Boza, F., Gallegos, C., (2005), Influence of Crumb Rubber Concentration on the Rheological Behavior of a Crumb Rubber Modified Bitumen, Energy Fuels., 19, pp. 1984-1990.

Phadke, A.A., Bhattacharya, A.K., Chakraborty, S.K., De, S.K., (1983), Studies of Vulcanization of Reclaimed Rubber. Rubber Chemistry and Technology, 56(4), pp. 726-736.

Prayitno, Supardal, dan Asrillah, (1990), Pengaruh Penambahan Karet Reclaim Terhadap Sifat Kuat Tarik, Kemuluran, dan Volume Terkikis Kompon Sol Karet, Majalah Kulit, Karet dan Plastik, V(9), pp. 1989/1990.

Setyowati, P., Pramono, dan Supriyanto, (2006), Pemanfaatan Karet Riklim Dari Skrab Rubber Roll Untuk Kompon Sol Sepatu, Majalah Kulit, Karet dan Plastik, 22(1), pp. $38-44$ 
Shigeo, K., Inoue, K., Tanaka, H., and Sakai T., (1980), Pyrolysis Process for Scrap Tires, ACS Symposium Series Vol. 130, Thermal Conversion of Solid Wastes and Biomass Chapter 40, pp. 557-572.

Syabani MW., Perdana I., Rochmadi, (2017), Thermal Degradation of Modified PhenolFormaldehyde Resin with Sodium Silicate, Proceeding International Conference on Chemistry and Engineering in Agroindustry (ICoCheA 2017), Padang, pp. 37-40.

Yu, H., Leng, Z., Gao, Z., (2016), Thermal Analysis on the Component Interaction of Asphalt Binders Modified with Crumb Rubber and Warm Mix Additives, Constr. Build. Mater. 125: 168-174.

Yuniari, A., (2006), Pemanfaatan Ter sebagai Softener dalam pembuatan karet reklim, Majalah Kulit Karet dan Plastik. 22(1), pp. 26-31

Yuniari, A., Sholeh, M., Indrajati, I.N., (2013), Pengaruh Sistem Vulkanisasi Konvensional (CV) dan Semi Efisien (SEV) terhadap Sifat Aging dan Termal Vulkanisat Campuran Karet Alam dan Karet Butil, Majalah Kulit Karet dan Plastik. 31(2), pp. 99-106 